\title{
Hepatic cysteine sulphinic acid decarboxylase depletion and defective taurine metabolism in a rat partial nephrectomy model of chronic kidney disease
}

Nima Abbasian ${ }^{1,2^{*}}$ (D, Maryam Ghaderi-Najafabadi ${ }^{1}$, Emma Watson ${ }^{3}$, Jeremy Brown ${ }^{3}$, Li Yu si ${ }^{1}$, Debbie Bursnall ${ }^{4}$, Izabella Pawluczyk ${ }^{3}$, Anne-Marie Seymour ${ }^{5}$ and Alan Bevington ${ }^{*}$

\begin{abstract}
Background: Taurine depletion occurs in patients with end-stage chronic kidney disease (CKD). In contrast, in the absence of CKD, plasma taurine is reported to increase following dietary L-glutamine supplementation. This study tested the hypothesis that taurine biosynthesis decreases in a rat CKD model, but is rectified by L-glutamine supplementation.

Methods: CKD was induced by partial nephrectomy in male Sprague-Dawley rats, followed 2 weeks later by 2 weeks of $12 \% \mathrm{w} / \mathrm{w}$ L-glutamine supplemented diet (designated NxT) or control diet (NxC). Sham-operated control rats $(S)$ received control diet.

Results: Taurine concentration in plasma, liver and skeletal muscle was not depleted, but steady-state urinary taurine excretion (a measure of whole-body taurine biosynthesis) was strongly suppressed (28.3 \pm 8.7 in NxC rats versus $78.5 \pm 7.6 \mu \mathrm{mol} / 24 \mathrm{~h}$ in $\mathrm{S}, P<0.05$ ), accompanied by reduced taurine clearance ( $\mathrm{NxC} 0.14 \pm 0.05$ versus $0.70 \pm$ $0.11 \mathrm{ml} / \mathrm{min} / \mathrm{Kg}$ body weight in $\mathrm{S}, \mathrm{P}<0.05$ ). Hepatic expression of mRNAs encoding key enzymes of taurine biosynthesis (cysteine sulphinic acid decarboxylase (CSAD) and cysteine dioxygenase (CDO)) showed no statistically significant response to CKD (mean relative expression of CSAD and CDO in NxC versus S was $0.91 \pm 0.18$ and $0.87 \pm$ 0.14 respectively). Expression of $C D O$ protein was also unaffected. However, CSAD protein decreased strongly in $\mathrm{NxC}$ livers ( $45.0 \pm 16.8 \%$ of that in $\mathrm{S}$ livers, $P<0.005$ ). L-glutamine supplementation failed to rectify taurine biosynthesis or CSAD protein expression, but worsened CKD (proteinuria in NxT $12.5 \pm 1.2$ versus $6.7 \pm 1.5 \mathrm{mg} / 24 \mathrm{~h}$ in $\mathrm{N} \times \mathrm{C}, \mathrm{P}<0.05)$.
\end{abstract}

Conclusion: In CKD, hepatic CSAD is depleted and taurine biosynthesis impaired. This is important in view of taurine's reported protective effect against cardio-vascular disease - the leading cause of death in human CKD.

Keywords: Chronic kidney disease, Cysteine sulphinic acid decarboxylase, L-glutamine, Sulphinoalanine decarboxylase, Taurine

\footnotetext{
*Correspondence: Abbasian.n.174@gmail.com; 57rrd1955@gmail.com

'Department of Respiratory Sciences, University of Leicester, Leicester LE1

$7 \mathrm{RH}, \mathrm{UK}$

Full list of author information is available at the end of the article
}

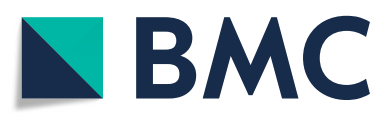

(c) The Author(s). 2021 Open Access This article is licensed under a Creative Commons Attribution 4.0 International License, which permits use, sharing, adaptation, distribution and reproduction in any medium or format, as long as you give appropriate credit to the original author(s) and the source, provide a link to the Creative Commons licence, and indicate if changes were made. The images or other third party material in this article are included in the article's Creative Commons licence, unless indicated otherwise in a credit line to the material. If material is not included in the article's Creative Commons licence and your intended use is not permitted by statutory regulation or exceeds the permitted use, you will need to obtain permission directly from the copyright holder. To view a copy of this licence, visit http://creativecommons.org/licenses/by/4.0/. The Creative Commons Public Domain Dedication waiver (http://creativecommons.org/publicdomain/zero/1.0/) applies to the data made available in this article, unless otherwise stated in a credit line to the data. 


\section{Background}

There is considerable evidence that both acute kidney injury and chronic kidney disease (CKD) lead in humans and in animal models to secondary defects in distant organs [1] including the liver [1-3]. The mechanism of this coupling between kidney and liver is poorly understood, but the chronic systemic inflammation that occurs in CKD may exert effects on liver [3], and the stressactivated MAP kinase P38 MAPK has been shown to mediate inflammatory effects, and also promote further release of inflammatory cytokines, in several models of inflammatory liver injury [4-9]. It has been proposed $[10,11]$ that the hepatic metabolic pathways that are affected during CKD include the catabolism pathways of the sulphur amino acids L-methionine and L-cysteine, which normally culminate in generation of sulphurous and sulphuric acid, and the sulphur amino acid taurine [12-14]. An abnormally low concentration of taurine has been reported in the blood plasma of end-stage CKD patients receiving dialysis therapy $[10,11]$. It has been speculated that this arises from insufficiency of the enzyme cysteine sulphinic acid decarboxylase (CSAD) which plays a role in taurine biosynthesis by catalysing the conversion of cysteine sulphinic acid (CSA) to hypotaurine which is the immediate precursor of taurine [13]. Another enzyme important here is cysteine dioxygenase (CDO) upstream of CSAD which generates CSA, and is regarded as a further site of metabolic control over sulphur amino acid catabolism in liver [13]. An alternative pathway through the enzyme cysteamine (2-aminoethanethiol) dioxygenase also exists, but is regarded as a minor contributor to taurine biosynthesis [15].

Taurine depletion in CKD is undesirable [10] in view of taurine's physiological importance [16], notably its reported protective effect [17] against endothelial dysfunction and inflammatory cardio-vascular disease which is the leading cause of death in patients with advanced CKD [18]. It has been proposed that taurine depleted patients with CKD could be treated by giving a taurine supplement, for example in dialysis fluid [19] or as an oral supplement [20]. However, such supplementation has been reported to be hazardous, as it may be difficult to control in CKD patients, leading to severe hypertaurinaemia [20]. If the impaired taurine biosynthesis suggested above is the cause of taurine depletion in CKD, an alternative approach with less risk of accidental hypertaurinaemia might be to rectify the impaired biosynthesis. The plasma concentration of taurine, both in rats and humans with intact renal function, has been reported to increase in response to dietary supplementation with L-glutamine [21] and the inward flux of taurine into liver, kidneys and gut was also reported to increase in the L-glutamine supplemented rats in that study [21]. However, whether L-glutamine supplementation can exert similar beneficial effects on taurine in the presence of CKD is unknown. Lglutamine is also a potentially attractive supplement to test in CKD in view of its reported (but disputed [22]) anabolic effects, notably in skeletal muscle.

The aim of this study was therefore to investigate defective taurine metabolism and its response to Lglutamine supplementation in a rat partial nephrectomy model of CKD. The hypothesis to be tested was that (a) depletion of the enzyme CSAD occurs in the liver of CKD rats compared with sham operated animals with intact renal function, and (b) that dietary L-glutamine supplementation rectifies the resulting defect in taurine metabolism.

\section{Methods}

Rat partial nephrectomy (Nx) model of CKD

All surgical and experimental procedures were performed subject to project licence reference PPL 80/2348 under the Animals (Scientific Procedures) Act (United Kingdom, 1986), and were approved by the University of Leicester Animal Welfare and Ethical Review Body.

The rat model of CKD (designated "Nx") was established in $250 \mathrm{~g}$ male Sprague-Dawley rats using a onestage surgical procedure as described previously [23]. All animals were obtained from Charles River Laboratories, Kent, UK. Briefly, rats were anaesthetised (3.5\% isoflurane in oxygen delivered at 21 per min), accompanied by sub-cutaneous administration of Rimadyl (Carpofen) 4 $\mathrm{mg} / \mathrm{Kg}$ body weight) for post-operative analgesia. Anaesthesia was maintained during surgery using $2.5 \%$ isoflurane in oxygen at $1 \mathrm{l} / \mathrm{min}$. The foot withdrawal reflex was tested to confirm anaesthesia. A $2 \mathrm{~cm}$ mid-line abdominal incision was made just below the sternum, and the left kidney was exposed and decapsulated, followed by clamping of the vasculature in the stem of the kidney with a $6 \mathrm{~mm}$ aneurysm clip. Approximately half $(\sim 0.4 \mathrm{~g})$ of the kidney was excised (mainly from the cortex). Following removal of the clamping, bleeding was controlled by applying Surgicel $^{\oplus}$ haemostat (BUNZL Healthcare, Coalville, UK) and the kidney remnant was repositioned in the animal. The right kidney was then externalised and decapsulated. Following ligation of the renal vasculature with a Mersilk ${ }^{\circledR}$ (Vicryl 0) non-absorbable suture (Johnson \& Johnson, Maidenhead, Berkshire, UK) the kidney was excised, and $5 \mathrm{ml}$ of $0.9 \% \mathrm{w} / \mathrm{v}$ sterile $\mathrm{NaCl}$ was applied in the peritoneal cavity to compensate for fluid loss during the surgery. An absorbable suture (Ethicon Vicryl $l^{\circledR}$ 3.0, Johnson \& Johnson, Maidenhead, Berkshire, UK) was then used to close the abdominal muscle layer, followed by closure of the skin with an Ethicon Vicryl 5/0 suture (Johnson \& Johnson, Maidenhead, Berkshire, UK). 
Sham-operated control rats (designated "S") were treated as above, with exposure and decapsulation of both kidneys, but no excision of tissue.

\section{Study design}

Following a 14 day post-surgery recovery period on control diet containing $14.38 \%$ crude protein and no taurine (Rat and Mouse No 1 Maintenance diet expanded form RM1(E) (Product Code 801002, Special Diets Services, Essex, UK) with water ad libitum, rats were assigned for a 14 day period to three experimental groups $(n=8$ in each group) designated $\mathrm{NxC}$ (partially nephrectomised CKD rats receiving control diet), NxT (partially nephrectomised CKD rats receiving test diet supplemented with L-glutamine), and S (sham-operated control animals receiving control diet).

\section{Test diet}

Animals in the NxT group received the control diet above supplemented with $12 \%$ L-glutamine by weight [21]. In the previously reported study [21], an isocaloric isonitrogenous supplement of control amino acids was administered to the control rats that were not receiving the L-glutamine supplement. This controlled for the effect of displacement of other nutrients in each $\mathrm{Kg}$ of diet by the substantial mass of L-glutamine. However, in the context of CKD, the nitrogen load associated with Lglutamine supplementation may be detrimental by worsening azotaemia. To allow the magnitude of this effect of L-glutamine to be assessed in this CKD model, the control CKD rats in Group $\mathrm{NxC}$ received control diet without a supplement of control amino acids.

Throughout the 14 day experimental period, the rats were housed individually in sets of 3 adjacent cages with one $\mathrm{NxC}$, one $\mathrm{NxT}$ and one $\mathrm{S}$ rat in each set. This was done to minimise systematic effects of environmental differences (e.g. small gradients in temperature, humidity or lighting) across the facility in which the animals were housed. The $\mathrm{S}$ rat in each set was pair fed with the accompanying $\mathrm{NxC}$ and NxT rats. Water was provided ad libitum. On the last day of the experimental period the rats were housed in metabolic cages to allow collection of urine. At the end of the urine collection, the animals were killed by exsanguination under terminal anaesthesia. Blood was collected by aortic cannulation into heparinised containers, and organs were removed, weighed and frozen in liquid nitrogen.

\section{Assessment of renal and liver function}

Creatinine and urea in urine and plasma were assayed colorimetrically using QuantiChrom ${ }^{\circ}$ assay kits (Universal Biologicals, Cambridge, UK) according to the manufacturer's instructions. Total urinary protein was determined by precipitation with trichloro-acetic acid followed by a colorimetric biuret assay [24]. Sulphate $\left(\mathrm{SO}_{4}{ }^{2-}\right.$ ) excretion in urine was assayed (following removal of urinary protein by precipitation with trichloroacetic acid), by addition of barium chloride and assay of the resulting precipitate of barium sulphate by turbidimetry [25]. The liver function test enzyme alanine transaminase (ALT) was assayed in plasma using a colorimetric catalytic assay kit (Sigma-Aldrich, Gillingham, UK) according to the manufacturer's instructions.

Renal clearance of creatinine and taurine (expressed as $\mathrm{ml} / \mathrm{min} / \mathrm{Kg}$ body weight) was calculated using the following formula [23]:

$$
\left(\left(\mathrm{C}_{\mathrm{u}} / \mathrm{C}_{\mathrm{p}}\right) \times \mathrm{V}_{\mathrm{u}}\right) / \mathrm{BW}
$$

where $C_{u}$ is the concentration of the solute in urine, $\mathrm{C}_{\mathrm{p}}$ is the concentration of the solute in plasma, $\mathrm{V}_{\mathrm{u}}$ is the average rate of urine production (in ml per minute) during the urine collection period, and $\mathrm{BW}$ is the body weight in $\mathrm{Kg}$.

\section{Assessment of body composition}

Twenty mg samples of frozen liver were homogenised in $800 \mu \mathrm{l}$ of ice-cold $0.3 \mathrm{M}$ perchloric acid and centrifuged for $10 \mathrm{~min}$ at $4{ }^{\circ} \mathrm{C}$ and $3000 \times \mathrm{g}$ to sediment acidinsoluble material which was assayed for total protein [26] and total DNA [27]. Acid in the supernatant was neutralised by vortexing with an equal volume of tri-noctylamine: 1,1,2-trichloro, trifluoro-ethane (22:78 vol/ vol) [28] and the top (aqueous) phase was removed and stored at $-80^{\circ} \mathrm{C}$ for subsequent analysis of free amino acids. Free amino acids (including taurine) were subjected to pre-column derivatization with ophthalaldehyde/3-mercaptopropionate/9-fluorenyl-

methylchloroformate, and the derivatives were separated on an Agilent 1100 high-performance liquid chromatograph with a Zorbax Eclipse AAA $(4.6 \times 75 \mathrm{~mm}, 3.5 \mu \mathrm{m})$ column at $40^{\circ} \mathrm{C}$ and quantified by post-column ultraviolet detection. As skeletal muscle contains the body's largest pool of lean tissue and of free amino acids (including taurine), the same procedures were also applied to fast-twitch muscle (gastrocnemius) and slowtwitch muscle (soleus) from each rat.

Amino acids in plasma were assayed following deproteinisation of $500 \mu \mathrm{l}$ aliquots of plasma with $12.5 \mu \mathrm{l}$ aliquots of $12 \mathrm{M}$ perchloric acid and neutralisation as described above.

\section{RNA extraction and qRT-PCR}

Total RNA was extracted using TRIzol reagent (Invitrogen, Paisley, UK). Using $1 \mu \mathrm{g}$ total RNA, cDNA was synthesized using an AMV reverse transcription system (Promega, Southampton, UK) according to the manufacturer's instructions. Forward and reverse primer 
sequences used in this study are listed in Table 1. Realtime PCR was performed using an Applied Biosystems 7500 Fast Real-Time PCR System (Thermo Fisher Scientific, Loughborough, UK) using SYBR green PCR reagent (Thermo Fisher Scientific, Loughborough, UK). Relative amounts of mRNA were normalized to the corresponding cyclophilin A signal for each sample, and relative expression is presented as $\left(2^{-\Delta \Delta C T}\right)$ [29].

\section{Immunoblotting}

Cell lysates from each rat were subjected to SDS-PAGE (30 $\mu \mathrm{g}$ protein per lane) followed by immunoblotting. Immunoblotting was performed onto nitrocellulose membranes (GE-Healthcare, Little Chalfont, UK) followed by probing with primary antibodies against: dually phosphorylated (P-Thr ${ }^{183} / \mathrm{P}-\mathrm{Tyr}^{185}$ ) JNK2 (Promega, Southampton, UK); P38 MAPK (Cell Signaling Technology, London, UK); phosphorylated (P-Thr ${ }^{180} / \mathrm{P}-$ $\mathrm{Tyr}^{182}$ ) P38 MAPK (Cell Signaling Technology, London, UK); $\beta$-Actin (Sigma-Aldrich, Gillingham, UK); CSAD (custom antibody raised against peptide [C]-SLRGKKES PDYSQRLS-amide) (Cambridge Research Biochemicals, Billingham, UK); and CDO (a kind gift from Prof Martha Stipanuk, Cornell University, New York, USA). Polyclonal Rabbit Anti-Mouse and Goat Anti-Rabbit Immunoglobulins/HRP (DakoCytomation (Agilent), Santa Clara, USA) were used as secondary antibodies as appropriate and HRP-labelled proteins were detected by chemiluminescence using ECL reagent (GE-Healthcare, Little Chalfont, UK). Band intensities were quantified by Image Lab Software v 5.2.1 (Bio-Rad) and data are presented as the ratio of the intensity for the protein of interest/housekeeping protein expressed as a \% of the corresponding ratio under control conditions.

\section{Statistical analysis}

Analysis was performed using GraphPad Prism 8.1.2. Normally distributed data are expressed as Mean \pm SEM and were analysed by 1-way repeated measures ANOVA

Table 1 Primers used for qRT-PCR

\begin{tabular}{|c|c|c|}
\hline Gene & Primer sequence & \\
\hline \multirow[t]{2}{*}{ CSAD } & Forward 5' - 3' & AGATGATCCCTGAGGATCTG \\
\hline & Reverse $5^{\prime}-3^{\prime}$ & TGGATCCCATCCAGGAGATG \\
\hline \multirow[t]{2}{*}{ CDO } & Forward $5^{\prime}-3^{\prime}$ & GACTGGCCTGACAAGAAATC \\
\hline & Reverse $5^{\prime}-3^{\prime}$ & TACAAGTGAAGGCTCACAGC \\
\hline \multirow[t]{2}{*}{ TauT (SLC6A6) } & Forward $5^{\prime}-3^{\prime}$ & TCTTCATTGCCATCGTGTGC \\
\hline & Reverse $5^{\prime}-3^{\prime}$ & AGGCATACACCACTAGCTGC \\
\hline \multirow[t]{2}{*}{ GAT2 (SLC6A13) } & Forward $5^{\prime}-3^{\prime}$ & GAAGAACCGGAGGGAGATTC \\
\hline & Reverse $5^{\prime}-3^{\prime}$ & GAGAACAGGAAGGTTGCCAG \\
\hline \multirow[t]{2}{*}{ Cyclophilin A } & Forward $5^{\prime}-3^{\prime}$ & CACCGTGTTCTTCGACATC \\
\hline & Reverse $5^{\prime}-3^{\prime}$ & TGCTGTCTITGGAACTTTGTC \\
\hline
\end{tabular}

on the matched-fed groups, with Tukey's range test post hoc testing. Non-normally distributed data (determined by the Shapiro-Wilk test) are expressed as Median (Inter-quartile Range) and were analysed by Friedman's 1way ANOVA with Dunn's multiple comparisons post hoc testing.

\section{Results}

\section{Confirmation of the CKD model}

The animals in the 3 experimental groups were matched for initial body weight and weight of food consumed over the 14day experimental period (Table 2). Comparison of the partially nephrectomised rats in Groups $\mathrm{NxC}$ and $\mathrm{NxT}$ with the sham-operated rats in Group $\mathrm{S}$ showed moderately reduced glomerular filtration rate (GFR) (assessed from creatinine clearance) and moderate azotaemia (elevated plasma concentrations of urea and creatinine) (Table 2). Proteinuria also occurred, but only in the L-glutamine supplemented NxT animals (Table 2). In this short 14 day study, no significant cachexia was observed, judged from Day 14 body weight, body weight gain over the 14 days, skeletal muscle weights, heart weight or liver weight (Table 2). Assessment of protein mass in relation to cell number in these tissues, using the total protein/DNA ratio, also failed to detect significant cachexia (Table 2).

\section{Confirmation of L-glutamine supplementation}

Even though no significant increase in the concentration of free L-glutamine or its catabolite L-glutamate was detected in the plasma or tissues of the L-glutaminetreated NxT rats compared with the $\mathrm{NxC}$ group (Table 3), significantly enhanced urea excretion was observed in the urine of the NxT rats (Table 2) and measurement of urine volume showed significant diuresis in the NxT group (Table 2). No significant anabolic effect of L-glutamine was observed, judged from Day 14 body weight, 14 day body weight gain, skeletal muscle weights, heart weight, liver weight or total protein/DNA ratio in these tissues (Table 2). The nitrogen load accompanying this L-glutamine supplement also resulted in apparent worsening of azotaemia (plasma urea in Table 2) although this fell short of statistical significance $(P=0.064$ versus $\mathrm{NxC}$ ). No statistically significant difference in residual kidney mass was observed between the NxT group and the $\mathrm{NxC}$ group (Table 2).

A small increase in the urinary excretion of free Lglutamine and L-glutamate was detected in the NxT rats compared with the $\mathrm{NxC}$ group (Table 3) but, when expressed as moles of nitrogen per $24 \mathrm{~h}$, this increase was only about $0.1 \%$ of the corresponding increase in urinary urea nitrogen (Table 2). 
Table 2 Characterisation of the CKD model

\begin{tabular}{|c|c|c|c|}
\hline & $\begin{array}{l}\text { Sham-operated, on Control } \\
\text { diet, } S(n=8)\end{array}$ & $\begin{array}{l}\text { Partial nephrectomy, on Control } \\
\text { diet, } \mathrm{NxC}(n=8)\end{array}$ & $\begin{array}{l}\text { Partial nephrectomy, on Test } \\
\text { diet, NxT }(n=8)\end{array}$ \\
\hline \multicolumn{4}{|l|}{ Body composition } \\
\hline Body weight (Day minus 14) (g) & $313.0 \pm 14.5$ & $308.9 \pm 14.8$ & $307.1 \pm 15.1$ \\
\hline Body weight (Day 1) (g) & $335.6 \pm 15.9$ & $305.3 \pm 13.2^{*}$ & $305.3 \pm 13.7$ \\
\hline Body weight (Day 14) (g) & $374.0 \pm 13.4$ & $345.8 \pm 12.2^{*}$ & $333.0 \pm 12.8^{*}$ \\
\hline Body weight gain over days 1-14 (g) & $38.4 \pm 5.6$ & $40.5 \pm 5.0$ & $27.7 \pm 4.2$ \\
\hline Food consumed over days 1-14 (g) & $317.5 \pm 12.3$ & $320.0 \pm 12.6$ & $312.7 \pm 11.1$ \\
\hline \multicolumn{4}{|l|}{ Gastrocnemius (mean of left \& right) } \\
\hline Wet weight (g) & $2.43 \pm 0.08$ & $2.25 \pm 0.07$ & $2.16 \pm 0.12$ \\
\hline Protein $(\mu \mathrm{g}$ per $\mu \mathrm{g}$ of $\mathrm{DNA})$ & $142(121-182)$ & $140(111-164)$ & $184(117-281)$ \\
\hline \multicolumn{4}{|l|}{ Soleus (mean of left \& right) } \\
\hline Wet weight (g) & $0.171 \pm 0.013$ & $0.163 \pm 0.006$ & $0.180 \pm 0.023$ \\
\hline Protein $(\mu \mathrm{g}$ per $\mu \mathrm{g}$ of $\mathrm{DNA})$ & $62(50-71)$ & $58(50-76)$ & $59(43-65)$ \\
\hline \multicolumn{4}{|l|}{ Heart } \\
\hline Wet weight (g) & $1.237 \pm 0.054$ & $1.109 \pm 0.042$ & $1.192 \pm 0.045$ \\
\hline Protein $(\mu \mathrm{g}$ per $\mu \mathrm{g}$ of $\mathrm{DNA})$ & $139(67-223)$ & $120(46-197)$ & $137(72-457)$ \\
\hline \multicolumn{4}{|l|}{ Liver } \\
\hline Wet weight (g) & $12.27 \pm 0.88$ & $10.55 \pm 0.29$ & $11.28 \pm 0.63$ \\
\hline Protein $(\mu \mathrm{g}$ per $\mu \mathrm{g}$ of $\mathrm{DNA})$ & $35(32-42)$ & $35(26-85)$ & $30(25-61)$ \\
\hline \multicolumn{4}{|l|}{ Left kidney } \\
\hline Wet weight (g) & $1.217 \pm 0.041$ & $1.268 \pm 0.064$ & $1.374 \pm 0.099$ \\
\hline \multicolumn{4}{|l|}{ Plasma parameters } \\
\hline Creatinine $(\mu \mathrm{M})$ & $38.44 \pm 2.56$ & $92.60 \pm 7.95^{*}$ & $115.65 \pm 29.06$ \\
\hline Urea (mM) & $4.36 \pm 0.72$ & $13.27 \pm 1.05^{*}$ & $26.44 \pm 4.23 * 9$ \\
\hline \multicolumn{4}{|l|}{$24 \mathrm{~h}$ Urinary excretion parameters } \\
\hline Creatinine $(\mu \mathrm{mol} / 24 \mathrm{~h})$ & $77.18 \pm 8.04$ & $68.89 \pm 9.17$ & $63.67 \pm 7.39$ \\
\hline Urea (mmol/24 h) & $9.72 \pm 0.94$ & $10.45 \pm 1.56$ & $25.11 \pm 2.76^{* 1}$ \\
\hline Total protein (mg/24 h) & $6.46 \pm 0.71$ & $6.74 \pm 1.50$ & $12.49 \pm 1.19^{* 1}$ \\
\hline Total volume (ml/24 h) & $14.64 \pm 1.31$ & $23.71 \pm 1.94^{*}$ & $53.45 \pm 4.57^{* 1}$ \\
\hline $\begin{array}{l}\text { Creatinine clearance (GFR) (ml/min/ } \\
\text { Kg body weight) }\end{array}$ & $4.06 \pm 0.47$ & $1.51 \pm 0.17^{*}$ & $1.51 \pm 0.35$ \\
\hline
\end{tabular}

Unless otherwise stated, all parameters refer to Day 14 (i.e. 28 days after surgery). Feeding of experimental diets was performed from Day 1 to Day 14 . Data are presented as Mean \pm SEM or as Median (inter-quartile range). ${ }^{*} P<0.05$ versus Sham; ${ }^{l} P<0.05$ versus $\mathrm{NxC} \mathbb{\Re} P=0.064$ versus NxC

\section{Effect of the CKD model on taurine and sulphate}

Even though the diet fed to all three experimental groups in this study contained no taurine, a significant rate of urinary taurine excretion was detected in all of the rats (Table 3). Comparison of this rate in the $\mathrm{NxC}$ CKD group with the control rate in sham operated group S, revealed a significant $64 \%$ fall in this taurine excretion rate in CKD and the urinary taurine $/ \mathrm{SO}_{4}{ }^{2-}$ ratio was also significantly decreased by $64 \%$ in the $\mathrm{NxC}$ group compared with the $\mathrm{S}$ group (Table 3 ). The total rate of sulphur excretion (taurine plus $\mathrm{SO}_{4}{ }^{2-}$ ) was $23 \%$ lower in the $\mathrm{NxC}$ group compared with the $\mathrm{S}$ group (Table 3). Mean total taurine plus $\mathrm{SO}_{4}{ }^{2-}$ excretion rate was also $11 \%$ lower in the $\mathrm{NxT}$ group than in the $\mathrm{NxC}$ group (Table 3).

In spite of the significant decline in the steady-state rate of appearance of taurine in the urine in the CKD rats (suggesting impaired taurine biosynthesis - see Discussion), there was no corresponding fall in the concentration of taurine in plasma, in liver or in muscle (Table 3). When the plasma taurine concentration and the rate of urinary taurine excretion were used to calculate taurine clearance (Table 3), this was found to be $81 \%$ lower in the $\mathrm{NxC}$ and $\mathrm{NxT}$ groups of CKD animals compared with the sham-operated control rats. 
Table 3 Effect of CKD and dietary L-glutamine supplementation on free amino acids and sulphate $\left(\mathrm{SO}_{4}{ }^{2-}\right)$

\begin{tabular}{|c|c|c|c|}
\hline & $\begin{array}{l}\text { Sham-operated, on Control } \\
\text { diet, } S(n=8)\end{array}$ & $\begin{array}{l}\text { Partial nephrectomy, on Control } \\
\text { diet, } \operatorname{NxC}(n=8)\end{array}$ & $\begin{array}{l}\text { Partial nephrectomy, on Test } \\
\text { diet, NxT }(n=8)\end{array}$ \\
\hline \multicolumn{4}{|l|}{ Tissue parameters } \\
\hline \multicolumn{4}{|l|}{ Gastrocnemius (mean of left \& right) } \\
\hline L-glutamine $(\mu \mathrm{mol} / \mathrm{g})$ & $5.48 \pm 1.00$ & $6.23 \pm 1.31$ & $5.61 \pm 0.87$ \\
\hline L-glutamate $(\mu \mathrm{mol} / \mathrm{g})$ & $1.20 \pm 0.44$ & $1.38 \pm 0.36$ & $1.51 \pm 0.47$ \\
\hline L-cysteine (nmol/g) & $44 \pm 14$ & $31 \pm 13$ & $27 \pm 15$ \\
\hline L-methionine (nmol/g) & $82 \pm 34$ & $98 \pm 36$ & $100 \pm 27$ \\
\hline Taurine $(\mu \mathrm{mol} / \mathrm{g})$ & $16.4 \pm 2.7$ & $15.6 \pm 2.1$ & $14.8 \pm 1.2$ \\
\hline \multicolumn{4}{|l|}{ Soleus (mean of left and right) } \\
\hline L-glutamine $(\mu \mathrm{mol} / \mathrm{g})$ & $12.0 \pm 2.7$ & $15.1 \pm 4.5$ & $18.1 \pm 6.1$ \\
\hline L-glutamate $(\mu \mathrm{mol} / \mathrm{g})$ & $3.89 \pm 1.25$ & $5.51 \pm 1.53$ & $6.78 \pm 1.75$ \\
\hline L-cysteine (nmol/g) & ND & ND & ND \\
\hline L-methionine (nmol/g) & $99 \pm 30$ & $96 \pm 23$ & $156 \pm 53$ \\
\hline Taurine $(\mu \mathrm{mol} / \mathrm{g})$ & $25.9 \pm 2.6$ & $25.7 \pm 1.7$ & $25.2 \pm 1.8$ \\
\hline \multicolumn{4}{|l|}{ Liver } \\
\hline L-glutamine $(\mu \mathrm{mol} / \mathrm{g})$ & $7.11 \pm 1.04$ & $8.10 \pm 1.13$ & $9.09 \pm 1.98$ \\
\hline L-glutamate $(\mu \mathrm{mol} / \mathrm{g})$ & $2.70 \pm 0.89$ & $1.76 \pm 0.54$ & $2.29 \pm 0.50$ \\
\hline L-cysteine (nmol/g) & ND & ND & ND \\
\hline L-methionine (nmol/g) & $139 \pm 20$ & $101 \pm 16$ & $208 \pm 45$ \\
\hline Taurine $(\mu \mathrm{mol} / \mathrm{g})$ & $5.04 \pm 1.51$ & $8.21 \pm 1.84$ & $8.05 \pm 1.71$ \\
\hline \multicolumn{4}{|l|}{ Plasma parameters } \\
\hline L-glutamine $(\mu \mathrm{M})$ & $830 \pm 63$ & $1067 \pm 163$ & $902 \pm 228$ \\
\hline L-glutamate ( $\mu \mathrm{M})$ & $92.6 \pm 23.8$ & $156.3 \pm 36.9$ & $174.0 \pm 46.4$ \\
\hline L-cysteine $(\mu \mathrm{M})$ & $29.9 \pm 4.2$ & $46.3 \pm 11.6$ & $41.0 \pm 8.4$ \\
\hline L-methionine ( $\mu \mathrm{M})$ & $70.9 \pm 18.1$ & $94.1 \pm 19.1$ & $79.9 \pm 15.8$ \\
\hline Taurine $(\mu \mathrm{M})$ & $289 \pm 93$ & $486 \pm 119$ & $354 \pm 135$ \\
\hline \multicolumn{4}{|l|}{$24 \mathrm{~h}$ Urinary excretion parameters } \\
\hline L-glutamine $(\mu \mathrm{mol} / 24 \mathrm{~h})$ & $0.42 \pm 0.22$ & $4.81 \pm 2.43$ & $17.88 \pm 5.62^{*}$ \\
\hline L-glutamate ( $\mu \mathrm{mol} / 24 \mathrm{~h})$ & $2.52 \pm 0.33$ & $1.72 \pm 0.56$ & $4.63 \pm 0.99$ \\
\hline Taurine $(\mu \mathrm{mol} / 24 \mathrm{~h})$ & $78.48 \pm 7.63$ & $28.25 \pm 8.65^{*}$ & $15.56 \pm 3.67^{*}$ \\
\hline Sulphate $\left(\mathrm{SO}_{4}{ }^{2-}\right)(\mu \mathrm{mol} / 24 \mathrm{~h})$ & $159.0 \pm 9.8$ & $155.2 \pm 18.7$ & $147.8 \pm 30.5$ \\
\hline $\begin{array}{l}\text { Taurine/sulphate }\left(\mathrm{SO}_{4}{ }^{2-}\right) \text { molar } \\
\text { ratio }\end{array}$ & $0.507 \pm 0.054$ & $0.181 \pm 0.048^{*}$ & $0.138 \pm 0.041^{*}$ \\
\hline $\begin{array}{l}\text { Total taurine }+ \text { sulphate }\left(\mathrm{SO}_{4}{ }^{2}\right. \\
-)(\mu \mathrm{mol} / 24 \mathrm{~h})\end{array}$ & $237.5 \pm 14.0$ & $183.4 \pm 22.1^{*}$ & $163.4 \pm 33.1^{*}$ \\
\hline $\begin{array}{l}\text { Taurine clearance }(\mathrm{ml} / \mathrm{min} / \mathrm{Kg} \\
\text { body weight) }\end{array}$ & $0.703 \pm 0.105$ & $0.136 \pm 0.053^{*}$ & $0.133 \pm 0.068^{*}$ \\
\hline
\end{tabular}

All parameters refer to Day 14 (i.e. 28 days after surgery). Feeding of experimental diets was performed from Day 1 to Day 14 . Concentrations in tissue are expressed as $\mathrm{nmol}$ or $\mu \mathrm{mol} / \mathrm{g}$ wet weight. Data are presented as Mean \pm SEM. ${ }^{*} P<0.05$ versus Sham. I $P<0.05$ versus NxC ND Not detectable

Measurements of L-methionine (Table 3) failed to detect any reproducible changes in plasma, liver or muscle in the $\mathrm{NxC}$ group compared with the $\mathrm{S}$ group that might have contributed to downstream effects on taurine. Similarly no significant changes in L-cysteine were observed in plasma and in gastrocnemius.

\section{Effect of CKD on liver}

When liver lysates were probed by immunoblotting, a tendency towards phospho-activation of the stressactivated MAP kinases JNK and P38 was detected in the CKD rats in the NxC group relative to the shamoperated control rats (Fig. 1a, b). However this did not 
a)

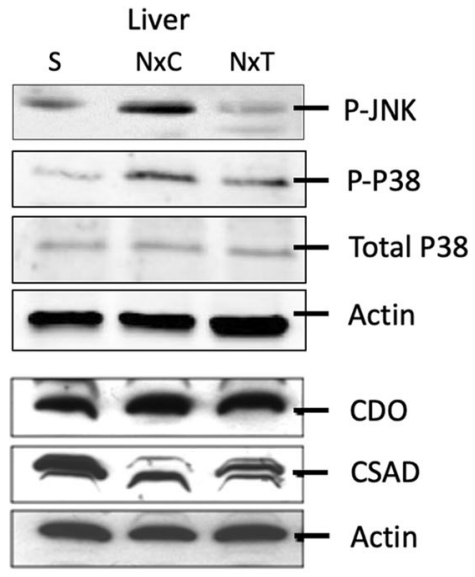

c)

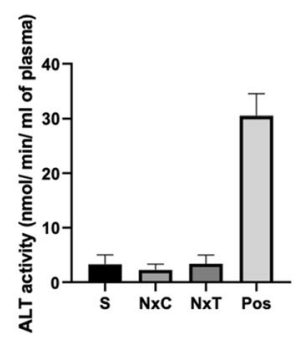

e)

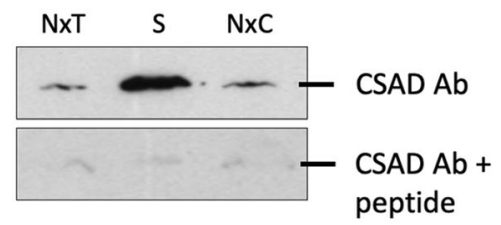

b)
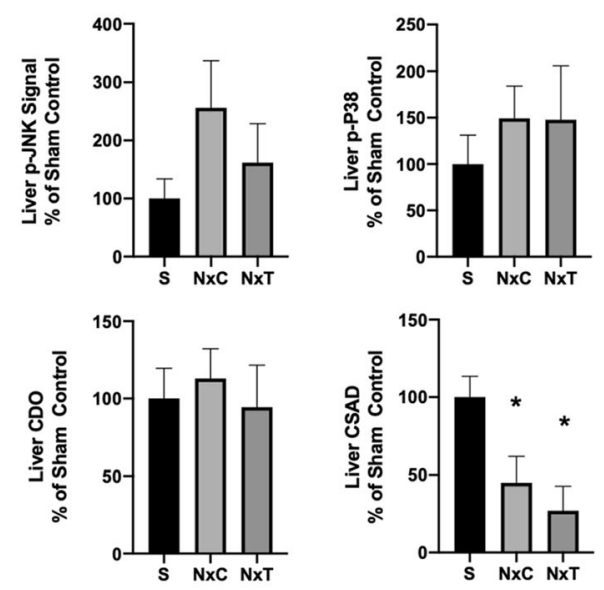

d)

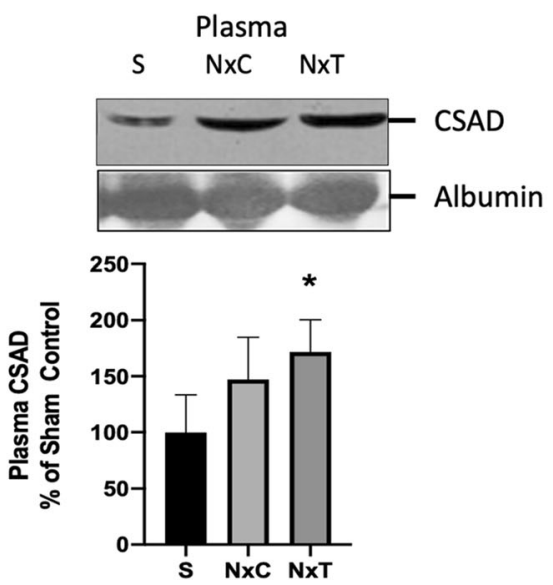

Fig. 1 Response of rat liver to CKD with (NxT) or without (NxC) dietary L-glutamine supplementation. S denotes sham-operated control rats. All data refer to Day 14 (i.e. 28 days after surgery). Feeding of experimental diets was performed from Day 1 to Day 14. a Representative immunoblots obtained from liver lysates using antibodies against P-JNK (dually phosphorylated (P-Thr ${ }^{183} /$ P-Tyr $^{185}$ ) JNK2); P-P38 (phosphorylated (P-Thr ${ }^{180} /$ P-Tyr ${ }^{182}$ ) P38 MAPK); Total P38 MAPK; $\beta$-Actin; CDO (cysteine dioxygenase); and CSAD (cysteine sulphinic acid decarboxylase). b Quantification of blots from (a) by densitometry. c Colorimetric catalytic assay for alanine transaminase (ALT) in plasma. POS denotes reading obtained with positive control provided in the assay kit. $\mathbf{d}$ Representative immunoblot obtained from blood plasma using antibody against CSAD, with albumin as loading control (top panel) and quantification of blots by densitometry (bottom panel). e CSAD immunoblot showing the effect of incubation with primary anti-CSAD antibody as in (a) (top panel); or overnight pre-incubation of primary antibody with antigenic blocking peptide [C]-SLRGKKESPDYSQRLS-amide at $10 \mu \mathrm{g} / \mathrm{ml}$ (bottom panel). Data are presented as Mean \pm SEM, $n=8$ rats in each group. ${ }^{*} P<0.05$ versus Sham

reach statistical significance $(P=0.072$ for $\mathrm{P}-\mathrm{JNK} ; P=$ 0.278 for P-P38). Furthermore, assay of the liver function test (LFT) enzyme alanine transaminase (ALT) in the rats' plasma detected no increase in the CKD animals (Fig. 1c).

qRT-PCR detected strong expression in liver of mRNAs encoding both CDO and CSAD, the two principal enzymes that regulate sulphur amino acid catabolism (Table 4). CKD had no statistically significant impact on the expression of CDO or CSAD mRNA (Table 4), but did up-regulate expression of the mRNA encoding taurine transporters GAT2 and TauT (Table 4).
In contrast, when expression of CSAD protein was assessed by immunoblotting in the livers of the $\mathrm{NxC}$ group of CKD rats, this showed a clear decrease to $45 \%$ of the value in sham operated control animals (S) (Fig. $1 \mathrm{a}, \mathrm{b})$, consistent with the reduction in the taurine flux into urine in the $\mathrm{NxC}$ group (36\% of the S value in Table 3 ) and the accompanying reduction in the urinary taurine/ $\mathrm{SO}_{4}{ }^{2-}$ excretion ratio (36\% of the $\mathrm{S}$ value in Table $3)$. Conversely, immunoblotting performed on plasma detected an apparent increase in the CSAD protein signal (Fig. 1d). Specificity of the signal observed in the CSAD immunoblots was confirmed by abolition of the signal (both in liver (Fig. 1e) and in plasma) on pre- 
Table 4 Effect of CKD and dietary L-glutamine supplementation on expression of mRNAs encoding regulatory enzymes of taurine biosynthesis and taurine transporters in rat liver on Day 14 (i.e. 28 days after surgery)

\begin{tabular}{llll}
\hline & $\begin{array}{l}\text { Sham-operated, on Control diet, S } \\
(\boldsymbol{n}=\mathbf{8})\end{array}$ & $\begin{array}{l}\text { Partial nephrectomy, on Control diet, NxC } \\
(\boldsymbol{n}=\mathbf{8})\end{array}$ & $\begin{array}{l}\text { Partial nephrectomy, on Test diet, NxT } \\
(\boldsymbol{n}=\mathbf{8})\end{array}$ \\
\hline Liver & & & \\
CSAD & $1.19 \pm 0.35$ & $0.91 \pm 0.18$ & $0.33 \pm 0.13$ \\
CDO & $1.08 \pm 0.20$ & $0.87 \pm 0.14$ & $1.00 \pm 0.14$ \\
TauT & $0.81(0.64-0.90)$ & $3.38(1.86-4.33)$ & $3.50(1.71-15.14)^{*}$ \\
(SLC6A6) & & & \\
GAT2 & $0.95(0.87-1.08)$ & $2.16(1.22-14.64)$ & $22.7(19.73-32.84)^{*}$ \\
(SLC6A13) & & &
\end{tabular}

Feeding of experimental diets was performed from Day 1 to Day 14. Relative amounts of mRNA were normalized to the corresponding cyclophilin A signal for each sample, and relative expression is presented as $\left(2^{-\Delta \Delta C T}\right)$. Data are presented as Mean \pm SEM or as Median (inter-quartile range). ${ }^{*} P<0.05$ versus Sham

incubating the primary antibody with the specific CSAD blocking peptide. Probing for expression of CDO protein in the same livers detected no change in response to CKD (Fig. 1a).

\section{Impact of L-glutamine on taurine in this CKD model}

In spite of the previously reported increase in plasma taurine concentration induced by L-glutamine in rats with intact renal function [21], dietary supplementation with L-glutamine failed to increase the taurine concentration in plasma in the present CKD model (Table 3), nor did it normalise the taurine $/ \mathrm{SO}_{4}{ }^{2-}$ ratio in urine (Table 3), or the CSAD protein expression in liver (Fig. $1 \mathrm{a}, \mathrm{b})$. Indeed the mean level of expression of CSAD mRNA seemed lower in the L-glutamine supplemented $\mathrm{NxT}$ group than in $\mathrm{S}$ and $\mathrm{NxC}$ (relative expression $0.33 \pm 0.13$ for NxT in Table 4), but this was not statistically significant.

\section{Discussion}

\section{Characterisation of the CKD model and L-glutamine supplementation}

In good agreement with earlier characterisation of this surgical model of CKD [23], the partially nephrectomised rats in groups $\mathrm{NxC}$ and $\mathrm{NxT}$ in the present study showed reduced GFR and moderate azotemia when compared with the sham-operated control animals (Table 2). In spite of failure to detect an increase in the plasma or tissue L-glutamine concentration in the L-glutamine supplemented NxT group (Table 3), there was good evidence for catabolism of the ingested L-glutamine resulting in enhanced urea excretion and consequently urea-induced osmotic diuresis (Table 2) which has previously been reported as a consequence of enhanced urea production in rats [30]. In spite of this, no significant anabolic effect of L-glutamine was observed (Table 2), indeed the 14 day body weight gain was lower in the $\mathrm{NxT}$ rats compared with the $\mathrm{NxC}$ group, possibly as a consequence of diuresis. Furthermore, in spite of the increased ureagenesis in the NxT rats, no significant increase in residual renal mass was observed in comparison with the $\mathrm{NxC}$ group (Table 2) in contrast with the urea-induced renal hypertrophy that has previously been reported in urea-supplemented rats with intact kidneys [30].

\section{Evidence of defective taurine metabolism}

The main strength of the present study is that it is the first to demonstrate by direct measurements in a rat model of CKD the hepatic depletion of CSAD, a key enzyme of taurine biosynthesis, accompanied by a marked reduction in the steady-state rate of appearance of taurine in the animals' urine and a decrease in the taurine/ sulphate excretion ratio (Fig. 1 and Table 3).

It has been suspected for more than 20 years that a defect exists in the hepatic biosynthesis of taurine in human patients with advanced CKD, both in predialysis patients [11] and in end-stage patients receiving dialysis $[10,11]$. The steady-state rate of appearance of taurine in the urine in the absence of dietary taurine has previously been used as a measure of the endogenous rate of taurine biosynthesis [31]. The decline in taurine excretion rate in Table 3 in the present study is therefore consistent with the impaired taurine biosynthesis arising from CSAD insufficiency that was previously proposed [10]. In liver, CSAD is the enzyme that partitions the sulphur amino acid flux between the pathway to taurine and the alternative pathway to sulphurous and sulphuric acid (which can be assessed by measuring sulphate $\mathrm{SO}_{4}{ }^{2-}$ excretion [31]). If the previously proposed insufficiency of CSAD in CKD [10] is occurring here, the ratio of taurine generation to $\mathrm{SO}_{4}{ }^{2-}$ generation would be expected to decrease. As predicted, this ratio did indeed decrease in the $\mathrm{NxC}$ group compared with the S group (Table 3), consistent with CSAD impairment (probably in the liver [32]).

If the metabolic flux through CSAD is impaired in the $\mathrm{NxC}$ group, a possible outcome is diversion of 
the flux of sulphur down the alternative pathway to $\mathrm{SO}_{4}{ }^{2-}$ resulting in increased $24 \mathrm{~h}$ excretion of $\mathrm{SO}_{4}{ }^{2-}$ in the $\mathrm{NxC}$ group compared with the sham-operated $\mathrm{S}$ group. This increase was not observed (Table 3) and, as a consequence, the total rate of sulphur excretion (taurine plus $\mathrm{SO}_{4}{ }^{2-}$ ) was lower in the $\mathrm{NxC}$ group compared with the $\mathrm{S}$ group (Table 3 ). The further observation that total taurine plus $\mathrm{SO}_{4}{ }^{2-}$ excretion rate was $11 \%$ lower in the NxT group than in the $\mathrm{NxC}$ group (Table 3) probably reflects the displacement of dietary sulphur amino acids in each $\mathrm{Kg}$ of diet by the $12 \%$ L-glutamine supplement.

\section{Mechanism of defective taurine metabolism in CKD}

In spite of the findings above, it is important to emphasise that a defect in hepatic biosynthesis is unlikely to be the only abnormality in taurine physiology in CKD, either in the current rat model or in end-stage human CKD. The observation here in the $\mathrm{NxC}$ rats of unaltered taurine concentration in plasma, liver and muscle (Table 3) in spite of a significant steady-state decline in the rate of appearance of taurine in the urine demonstrated a marked renal retention of taurine, with an $81 \%$ decrease in taurine clearance. Much of this retention may be attributable to the reduced GFR in this CKD model (demonstrated by the accompanying 63\% decrease in creatinine clearance (Table 2)). Such taurine retention may explain why, in non-taurine supplemented patients with end-stage renal failure, whose plasma taurine concentration is clearly low $[10,11]$, subsequent moderate oral taurine supplementation results in severe hypertaurinaemia that would not be observed with this level of supplementation in healthy individuals [20].

A further taurine abnormality observed here was that in the NxT group there was significantly enhanced hepatic expression of genes encoding taurine transporters TauT and GAT2 (Table 4) which perform inwardly directed active transport of taurine in hepatocytes [33, 34]. Compensatory up-regulation of the transporters to restore intra-hepatocyte taurine concentration in the face of CSAD insufficiency is a possible explanation. However, it should be noted that this gene expression effect did not reach statistical significance in the clearly CSAD-deficient $\mathrm{NxC}$ group (Table 4); and up-regulation of TauT mRNA was not observed in CSAD knock-out mice with normal renal function [15]. Uraemia may be a contributor to this CKD-induced transporter upregulation. This is supported by the fact that ureagenesis (shown by the high $24 \mathrm{~h}$ urea excretion rate) and plasma urea concentration in the NxT group were both twice as high as in the $\mathrm{NxC}$ group (Table 2), and may explain why the transporter up-regulation reached statistical significance in the NxT group but not in the $\mathrm{NxC}$ group (Table 4).

The observation here of a significant reduction in the $24 \mathrm{~h}$ flux of taurine into urine, implying impairment of taurine biosynthesis, could in principle have arisen from a decrease in the activity of additional enzymes other than just CSAD; for example CDO, the other major enzyme (upstream of CSAD) that influences sulphur amino acid catabolism in liver and hence the total rate of production of taurine plus sulphate $\left(\mathrm{SO}_{4}{ }^{2-}\right)$ [13]. Even though no significant decline in $\mathrm{CDO}$ expression at mRNA level or at protein level was detected in the $\mathrm{NxC}$ rats compared with the sham-operated control rats (Table 4 and Fig. 1a), a decline in the metabolic flux through CDO (possibly because of events upstream of CDO) cannot be ruled out. The occurrence of such additional effects of CKD (independent of CSAD) may explain why the total $24 \mathrm{~h}$ rate of taurine + sulphate $\left(\mathrm{SO}_{4}{ }^{2}\right.$ ${ }^{-}$) excretion into urine was $23 \%$ lower in the $\mathrm{NxC} \mathrm{CKD}$ group than in the sham-operated $\mathrm{S}$ group (Table 3 ). Theoretically depletion of sulphur amino acid substrates L-methionine and L-cysteine could have contributed to this decrease, but no evidence for such depletion in $\mathrm{NxC}$ versus $\mathrm{S}$ group rats was found in the plasma or tissue amino acid pools that were detectable in Table 3. Indeed, as in human skeletal muscle in an earlier report [35], free L-cysteine was not routinely detectable in soleus and liver in the present study.

There was no evidence in this study of significant transcriptional effects of CKD on CSAD expression in the $\mathrm{NxC}$ rats (Table 4). It therefore seems unlikely that the previously documented transcriptional regulation of CSAD by bile acids [36] was significantly disturbed here by the bile acid abnormalities that occur in end-stage CKD [37]. However, it should not be concluded from the present data that effects at mRNA level play no role in the taurine metabolism abnormalities described here. For example, even though it was not statistically significant, the marked downward trend in CSAD mRNA in the NxT group merits further investigation and it would be of interest in future work to examine the time course of CSAD and CDO mRNA in CKD.

It remains to be determined whether CKD affects post-transcriptional regulation of hepatic CSAD expression and whether this decreases the stability of the protein to proteolysis, or alters trafficking of the protein within the cell (possibly to the extracellular compartment - as implied by Fig. 1d). It has been reported that, at least in brain, CSAD is phosphorylated, a posttranslational modification which activates the enzyme [38]; and more recent studies have detected phosphorylation specifically at threonine residue 84 in human CSAD [39]). 


\section{Impact of L-glutamine supplementation}

Even though the 14-day dietary L-glutamine supplement was well tolerated by the partially nephrectomised rats in this study, it yielded no obvious benefits, either in terms of rectifying the taurine defect or in terms of body composition. It also worsened proteinuria and caused a significant increase in urinary urea excretion. The resulting urea-induced osmotic diuresis is clearly undesirable, not least because this effect of urea has been reported to cause clinically significant hypernatraemia in humans [40].

\section{Limitations of this study}

An earlier study of the effect of L-glutamine supplementation in rats with intact renal function [21] reported an increase in plasma L-glutamine and taurine concentration. Neither of these were observed in the present study. This difference may have arisen because the present study differs in two important respects from the earlier one: firstly because of the presence of CKD; secondly because the control (non-L-glutamine supplemented) rats here were not given the iso-caloric isonitrogenous load of control amino acids (comprising Lasparagine, L-serine, glycine, L-proline, and L-alanine) that was applied in the original study [21]. This change was made here to allow the effect of L-glutamine's accompanying calorie and nitrogen load to be assessed in the CKD rats. Displacement of other nutrients in each $\mathrm{Kg}$ of diet by the substantial mass of L-glutamine could in principle have affected the taurine status of the CKD rats. However, applying a heavy control load of non-Lglutamine neutral amino acids (as in the earlier study [21]) also risked confounding effects (e.g. by competitive inhibition or down-regulation of L-methionine transporters such as SNAT2/SLC38A2 which are regulated by neutral amino acid load [41]). As sham control groups receiving the test diet or the previously described non-L-glutamine neutral amino acid load [21] were not included in the present study, it was not possible to assess the effect of L-glutamine supplementation or the non-specific effects of other neutral amino acids on taurine metabolism in the absence of CKD. In future work such controls might be helpful to shed light on why Lglutamine failed here to show the previously reported [21] beneficial effects on taurine physiology.

A further limitation in this study was that no baseline collection of urine data was obtained from the rats at the start of the 14-day experimental period or before surgery. In principle any initial mismatching in baseline amino acid and sulphur metabolism between the groups of animals might have contributed to the failure to observe here the previously reported effect of L-glutamine supplementation on taurine metabolism. It is possible therefore that some beneficial effects of L-glutamine supplementation were overlooked in the present study as a consequence of this.

Finally, even though a number of other metabolic defects have been reported in liver in CKD [1-3], possibly occurring through the P38 MAP kinase-mediated inflammatory injury that is observed in models of liver injury [4-9], measurements of P38 and JNK MAP kinase activation in the present study detected no statistically significant activation of these kinases in the $\mathrm{NxC}$ rats (Fig. 1a, b), nor did measurements of the LFT enzyme ALT detect any abnormality (Fig. 1c). The mechanism linking CKD to the taurine defects described in this study therefore remains to be determined.

\section{Implications of defective CSAD in CKD}

This study is the first to report a substantial defect in the enzyme CSAD (and hence in taurine metabolism) in a pathological state (CKD) relevant to human disease. As it has been reported that taurine may play a significant role in prevention of endothelial and cardiovascular dysfunction [17], at least partly through its potent physiological [42] and anti-oxidant [16] effects, it is likely that CSAD insufficiency in CKD has pathological consequences, possibly contributing to the burden of cardiovascular disease which is the major cause of death [18] in CKD patients. This view is reinforced by evidence from CSAD knock-out mice in which there was considerable mortality in the mice accompanied by upregulation of genes encoding anti-oxidant enzymes [15], indicating oxidative stress. Significant oxidative stress is known to occur in the present partial nephrectomy CKD model when it is extended to 12 weeks post-surgery [23]. In the present relatively short 14 day study, commencing 14 days post-surgery, renal retention of taurine maintained the taurine pool size in the CKD model (Table 3) in spite of the CSAD depletion, but long-term taurine depletion is known to occur in advanced human CKD $[10,11]$ implying that the taurine retention effect observed here has limited duration. For this reason, further work on the molecular basis of hepatic CSAD depletion and long-term taurine abnormalities may be of value in reducing the burden of oxidative stress and cardiovascular mortality which are of such importance in patients with CKD.

\section{Supplementary Information}

The online version contains supplementary material available at https://doi. org/10.1186/s12882-021-02442-7.

\section{Additional file 1.}

Acknowledgements

The authors wish to thank the following for their contributions to this project: Prof Martha Stipanuk, Cornell University, New York, USA who kindly provided the CDO antibody; the staff of the Division of Biomedical Services, 
University of Leicester for their valuable support in developing the animal model and running the animal work; and Diane Balimo, Jing Ting Ma, Laura Tooley, and Samita Patel for their assistance with the sample processing and analytical work.

\section{Authors' contributions}

conception and design of research, N.A., I.P. and A.B.; funding acquisition, I.P. and A.B.; performing experiments, N.A., M.G-N., E.W., J.B., L.Y., D.B., A.B.; establishing and refining the animal model, D.B., A-M.S. and A.B.; preparing figures \& tables \& drafting manuscript, N.A. and A.B.; editing, revising \& approving final version of manuscript, N.A., M.G-N., E.W., J.B., L.Y., D.B., I.P.,A-M.S. and A.B. The author(s) read and approved the final manuscript.

\section{Funding}

This research was funded by an Innovations grant from Kidney Research UK (Ref IN92008).

\section{Availability of data and materials}

The datasets used and/or analysed during the current study are available from the corresponding authors on reasonable request.

\section{Declarations}

\section{Ethics approval and consent to participate}

The study was carried out in compliance with the ARRIVE guidelines (http:// www.nc3rs.org.uk/page.asp?id=1357), subject to project licence reference PPL 80/2348 under the Animals (Scientific Procedures) Act (United Kingdom, 1986), and was approved by the University of Leicester Animal Welfare and Ethical Review Body.

\section{Consent for publication}

Not applicable.

\section{Competing interests}

The authors declare that they have no competing interests.

\section{Author details}

${ }^{1}$ Department of Respiratory Sciences, University of Leicester, Leicester LE1 $7 \mathrm{RH}$, UK. ${ }^{2}$ School of Life and Medical Sciences, University of Hertfordshire, Hertfordshire, UK. ${ }^{3}$ Department of Cardiovascular Sciences, University of Leicester, Leicester, UK. ${ }^{4}$ Division of Biomedical Services, University of Leicester, Leicester, UK. ${ }^{5}$ School of Life Sciences (Biomedical), University of Hull, Hull, UK.

Received: 3 February 2021 Accepted: 4 June 2021

Published online: 05 July 2021

\section{References}

1. Grams ME, Rabb H. The distant organ effects of acute kidney injury. Kidney Int. 2012;81(10):942-8. https://doi.org/10.1038/ki.2011.241

2. Yeung CK, Shen DD, Thummel KE, Himmelfarb J. Effects of chronic kidney disease and uremia on hepatic drug metabolism and transport. Kidney Int. 2014;85(3):522-8. https://doi.org/10.1038/ki.2013.399.

3. Chapagain A, Caton PW, Kieswich J, Andrikopoulos P, Nayuni N, Long JH, et al. Elevated hepatic 11ß-hydroxysteroid dehydrogenase type 1 induces insulin resistance in uremia. Proc Natl Acad Sci U S A. 2014;111(10):3817-22. https://doi.org/10.1073/pnas.1312436111.

4. Kobayashi M, Takeyoshi I, Yoshinari D, Matsumoto K, Morishita Y. P38 mitogen-activated protein kinase inhibition attenuates ischemia-reperfusion injury of the rat liver. Surgery. 2002;131(3):344-9. https://doi.org/10.1067/ msy.2002.121097.

5. Chen X-L, Xia Z-F, Yu Y-X, Wei D, Wang C-R, Ben D-F. p38 mitogen-activated protein kinase inhibition attenuates burn-induced liver injury in rats. Burns: J Int Soc Burn Injuries. 2005;31(3):320-30. https://doi.org/10.1016/j.burns.2 004.10.015.

6. Klintman D, Li X, Santen S, Schramm R, Jeppsson B, Thorlacius H. p38 mitogen-activated protein kinase-dependent chemokine production, leukocyte recruitment, and hepatocellular apoptosis in endotoxemic liver injury. Ann Surg. 2005;242(6):830-8, discussion 838-9. https://doi.org/10.1 097/01.sla.0000189132.86878.f7.
7. Ignatova ID, Kostadinova RM, Goldring CE, Nawrocki AR, Frey FJ, Frey BM. Tumor necrosis factor-alpha upregulates 11 beta-hydroxysteroid dehydrogenase type 1 expression by CCAAT/enhancer binding protein-beta in HepG2 cells. Am J Phys Endocrinol Metab. 2009;296(2):E367-77. https:// doi.org/10.1152/ajpendo.90531.2008.

8. Lv K, Yu X, Bai Y, Zhu S, Tang H, Ben D, et al. Role of inhibition of p38 mitogen-activated protein kinase in liver dysfunction after hemorrhagic shock and resuscitation. J Surg Res. 2012;178(2):827-32. https://doi.org/10.1 016/j.jss.2012.04.006.

9. Sato H, Tanaka T, Tanaka N. The effect of p38 mitogen-activated protein kinase activation on inflammatory liver damage following hemorrhagic shock in rats. PLoS One. 2012;7(1):e30124. https://doi.org/10.1371/journal. pone.0030124.

10. Suliman ME, Anderstam B, Bergström J. Evidence of taurine depletion and accumulation of cysteinesulfinic acid in chronic dialysis patients. Kidney Int. 1996;50(5):1713-7. https://doi.org/10.1038/ki.1996.490.

11. Suliman ME, Anderstam B, Lindholm B, Bergström J. Total, free, and proteinbound Sulphur amino acids in uraemic patients. Nephrol Dial Transplant. 1997:12(11):2332-8. https://doi.org/10.1093/ndt/12.11.2332.

12. Stipanuk $\mathrm{MH}$. Role of the liver in regulation of body cysteine and taurine levels: a brief review. Neurochem Res. 2004;29(1):105-10. https://doi.org/10.1 023/b:nere.0000010438.40376.c9.

13. Stipanuk MH, Dominy JEJ, Lee J-I, Coloso RM. Mammalian cysteine metabolism: new insights into regulation of cysteine metabolism. J Nutr. 2006;136(6):1652S-9S. https://doi.org/10.1093/jn/136.6.1652S.

14. Stipanuk MH, Ueki I. Dealing with methionine/homocysteine sulfur: cysteine metabolism to taurine and inorganic sulfur. J Inherit Metab Dis. 2011;34(1): 17-32. https://doi.org/10.1007/s10545-009-9006-9.

15. Park E, Park SY, Dobkin C, Schuller-Levis G. Development of a novel cysteine sulfinic acid decarboxylase knockout mouse: dietary taurine reduces neonatal mortality. J Amino Acids. 2014;2014:346809-12. https://doi.org/1 $0.1155 / 2014 / 346809$

16. Jong CJ, Azuma J, Schaffer S. Mechanism underlying the antioxidant activity of taurine: prevention of mitochondrial oxidant production. Amino Acids. 2012;42(6):2223-32. https://doi.org/10.1007/s00726-011-0962-7.

17. Wesseling $S$, Koeners MP, Joles JA. Taurine: red bull or red herring? Hypertension. 2009;53:909-11. https://doi.org/10.1161/HYPERTENSIONAHA.1 09.130427.

18. Sarnak MJ, Amann K, Bangalore S, Cavalcante JL, Charytan DM, Craig JC, et al. Chronic kidney disease and coronary artery disease: JACC state-of-theart review. J Am Coll Cardiol. 2019;74(14):1823-38. https://doi.org/10.1016/j. jacc.2019.08.1017

19. Nishimura H, Ikehara O, Naito T, Higuchi C, Sanaka T. Evaluation of taurine as an osmotic agent for peritoneal dialysis solution. Perit Dial Int. 2009;29(2): 204-16. https://doi.org/10.1177/089686080902900216.

20. Suliman ME, Bárány P, Filho JCD, Lindholm B, Bergström J. Accumulation of taurine in patients with renal failure. Nephrol Dial Transplant. 2002;17(3): 528-9. https://doi.org/10.1093/ndt/17.3.528.

21. Boelens PG, Houdijk APJ, de Thouars HN, Teerlink T, van Engeland MIA, Haarman HJTM, et al. Plasma taurine concentrations increase after enteral glutamine supplementation in trauma patients and stressed rats. Am J Clin Nutr. 2003;77(1):250-6. https://doi.org/10.1093/ajen/77.1.250.

22. Gleeson M. Dosing and efficacy of glutamine supplementation in human exercise and sport training. J Nutr. 2008;138(10):2045S-9S. https://doi.org/1 0.1093/jn/138.10.2045S.

23. Nuhu F, Seymour A-M, Bhandari S. Impact of Intravenous Iron on Oxidative Stress and Mitochondrial Function in Experimental Chronic Kidney Disease. Antioxidants. 2019;8. https://doi.org/10.3390/antiox8100498.

24. Gowenlock AH. Varley's practical clinical biochemistry. Portsmouth: Heinemann; 1988

25. Ma RS, Chan JC. Endogenous sulphuric acid production: a method of measurement by extrapolation. Clin Biochem. 1973;6(2):82-7. https://doi. org/10.1016/s0009-9120(73)80016-5.

26. LOWRY OH, ROSEBROUGH NJ, FARR AL, RANDALL RJ. Protein measurement with the Folin phenol reagent. J Biol Chem. 1951;193(1):265-75. https://doi. org/10.1016/S0021-9258(19)52451-6.

27. GILES KW, MYERS A. An improved diphenylamine method for the estimation of deoxyribonucleic acid. Nature. 1965;206(4979):93. https://doi org/10.1038/206093a0. 
28. Khym JX. An analytical system for rapid separation of tissue nucleotides at low pressures on conventional anion exchangers. Clin Chem. 1975;21(9): 1245-52. https://doi.org/10.1093/clinchem/21.9.1245.

29. Livak KJ, Schmittgen TD. Analysis of relative gene expression data using real-time quantitative PCR and the 2(-Delta Delta C(T)) Method. Methods. 2001;25:402-8. https://doi.org/10.1006/meth.2001.1262.

30. Ogino Y, Okada S, Ota Z. Effects of chronic, urea-induced osmotic diuresis on kidney weight and function in rats. Diabetologia. 1994;37(3):225-31. https://doi.org/10.1007/BF00398047.

31. Nakamura H, Kajikawa R, Ubuka T. A study on the estimation of sulfurcontaining amino acid metabolism by the determination of urinary sulfate and taurine. Amino Acids. 2002;23(4):427-31. https://doi.org/10.1007/s00726002-0208-9.

32. Tappaz ML. Taurine biosynthetic enzymes and taurine transporter: molecular identification and regulations. Neurochem Res. 2004;29(1):83-96. https://doi. org/10.1023/b:nere.0000010436.44223.f8.

33. Zhou Y, Holmseth S, Guo C, Hassel B, Höfner G, Huitfeldt HS, et al. Deletion of the $\gamma$-aminobutyric acid transporter 2 (GAT2 and SLC6A13) gene in mice leads to changes in liver and brain taurine contents. J Biol Chem. 2012; 287(42):35733-46. https://doi.org/10.1074/jbc.M112.368175.

34. Qvartskhava N, Jin CJ, Buschmann T, Albrecht U, Bode JG, Monhasery N, et al. Taurine transporter (TauT) deficiency impairs ammonia detoxification in mouse liver. Proc Natl Acad Sci U S A. 2019;116(13):6313-8. https://doi. org/10.1073/pnas.1813100116.

35. Bergström J, Alvestrand A, Fürst P. Plasma and muscle free amino acids in maintenance hemodialysis patients without protein malnutrition. Kidney Int 1990;38(1):108-14. https://doi.org/10.1038/ki.1990.174.

36. Kerr TA, Matsumoto Y, Matsumoto H, Xie Y, Hirschberger LL, Stipanuk MH, et al. Cysteine sulfinic acid decarboxylase regulation: a role for farnesoid $X$ receptor and small heterodimer partner in murine hepatic taurine metabolism. Hepatol Res. 2014;44(10):E218-28. https://doi.org/10.1111/ hepr.12230.

37. Li R, Zeng L, Xie S, Chen J, Yu Y, Zhong L. Targeted metabolomics study of serum bile acid profile in patients with end-stage renal disease undergoing hemodialysis. Peer. 2019;7:e7145. https://doi.org/10.7717/peerj.7145.

38. Tang XW, Hsu CC, Schloss JV, Faiman MD, Wu E, Yang CY, et al. Protein phosphorylation and taurine biosynthesis in vivo and in vitro. J Neurosci. 1997;17(18):6947-51. https://doi.org/10.1523/JNEUROSCl.17-18-06947.1997.

39. Mertins P, Yang F, Liu T, Mani DR, Petyuk VA, Gillette MA, et al. Ischemia in tumors induces early and sustained phosphorylation changes in stress kinase pathways but does not affect global protein levels. Mol Cell Proteomics. 2014;13(7):1690-704. https://doi.org/10.1074/mcp.M113.036392.

40. Anderson A, Barrett EJ. Severe hypernatremia from a urea-induced diuresis due to body protein wasting in an insulin-resistant type 2 diabetic patient. Clin Endocrinol Metab. 2013;98(5):1800-2. https://doi.org/10.1210/jc.2 012-3225.

41. Hoffmann TM, Cwiklinski E, Shah DS, Stretton C, Hyde R, Taylor PM, et al. Effects of sodium and amino acid substrate availability upon the expression and stability of the SNAT2 (SLC38A2) amino acid transporter. Front Pharmacol. 2018;9:63. https://doi.org/10.3389/fphar.2018.00063.

42. Lambert IH, Kristensen DM, Holm JB, Mortensen OH. Physiological role of taurine--from organism to organelle. Acta Physiologica. 2015;213:191-212. https://doi.org/10.1111/apha.12365.

\section{Publisher's Note}

Springer Nature remains neutral with regard to jurisdictional claims in published maps and institutional affiliations.

Ready to submit your research? Choose BMC and benefit from:
- fast, convenient online submission
- thorough peer review by experienced researchers in your field
- rapid publication on acceptance
- support for research data, including large and complex data types
- gold Open Access which fosters wider collaboration and increased citations
- maximum visibility for your research: over 100M website views per year
At BMC, research is always in progress.
Learn more biomedcentral.com/submissions

